\title{
KLASIFIKASI DAN SIFAT MATERIAL TEKNIK SERTA PENGUJIAN MATERIAL
}

\section{Wahyu Hidayat}

Material - material yang sering digunakan didalam masalah teknik di bagi menjadi empat kelompok besar yaitu :

1. Logam

2. Keramik

3. Polimer

4. Komposit

\section{Logam}

Logam yang digunakan sebagai bahan teknik secara umum terbagi menjadi 2 yaitu :

1. Logam berbahan dasar Fe (Ferro) atau besi

2. Logam yang tidak berbahan dasar Ferro (non-Ferro)

Sifat -sifat umum dari logam diantaranya :

- Konduktifitas listrik dan termal yang tinggi

- Sifat-sifat mekanik (kekerasan dan kekuatan) umumnya tinggi

- Masa Jenis relatif tinggi

- Bersifat korosi

- Warna yang khas dan tidak transparan

Logam berbahan dasar Fe (Besi) di antaranya : 


\section{Baja}

Baja adalah perpaduan antara $\mathrm{Fe}$ dan $\mathrm{C}$ (besi dan karbon), karbon maksimum dari baja adalah 2,1\%. Karbon didalam baja membentuk karbida besi ( $\mathrm{Fe}_{3} \mathrm{C}$ atau Sementit)

Berdasarkan komposisi kimia baja dapat di bagi menjadi :

@. Baja karbon rendah $=\% \mathrm{C}<0.2 \%$

@. Baja Karbon sedang $=0.2>\% \mathrm{C}<0.5$

@. Baja karbon Sedang $=\%$ C $>0.5 \%$

\section{Baja Paduan}

Baja terdiri dari unsur utama yaitu $\mathrm{Fe}+\mathrm{C}$, tetapi dalam pembuatan baja tersebut ditambahkan unsur-unsur paduan yang dapat mempengaruhi sifat-sifat dari baja tersebut. Unsur - unsur paduan yang biasa ditambahkan dalam pembuatan baja seperti $\mathrm{Mn}, \mathrm{Al}, \mathrm{Ni}, \mathrm{Cr}, \mathrm{S}, \mathrm{P}, \mathrm{Mg}, \mathrm{Si}$, dan unsur paduan lainnya.

Baja paduan di bagi berdasarkan jumlah persentase unsur paduan yang ditambahkan.

@ baja paduan rendah = apabila jumlah unsur paduannya $<5 \%$, jumlah ini tidak merubah sifat baja secara luas.

@ baja paduan tinggi = apabila jumlah unsur paduannya $>5 \%$, jumlah ini akan mempengaruhi sifat baja secara luas contoh : baja tahan karat dengan unsur paduan $\mathrm{Cr}>12 \%$.

Berdasarkan fungsinya secara umum baja dapat dibagi menjadi 3 yaitu :

-) baja Konstruksi

-) Baja Perkakas

-) Baja Temperatur tinggi

\section{Besi Cor}


Besi cor terdiri dari unsur utama yaitu $\mathrm{Fe}+\mathrm{C}$, tetapi presentase karbon pada besi cor lebih dari 2,1\%. Karbon bebas dari besi cor berupa Grafit yang memiliki sifat getas.

Kita bisa membedakan jenis besi cor dari bentuk grafitnya tersebut, dari bentuk grafit-nya besi cor bisa diklasifikasikan secara umum sebagai berikut :

*) Besi cor putih ( tidak memiliki grafit dan sifatnya hampir sama dengan baja karbon tinggi)

*) Besi Cor Kelabu (grafit berbentuk pipih)

*) Besi cor nodular (grafit berbentuk bulat)

*) Besi cor maliable( grafit berbentuk bunga)

\section{KERAMIK}

Klasifikasi dari keramik :

\section{Bahan ORGANIK bukan LOGAM}

Penggunaan dan pemakaiannya pada temperatur tinggi

2. Bahan dari senyawa LOGAM

(oksida,barida, karbida,dan nitrida)

Penggunaan keramik biasanya untuk Isolator, komponen-komponen abrasif, dapat digunakan sebagai lapisan penghalang termal contoh Batu Tahan Api (BTA).

Sifat-sifat umum dari Keramik

- Keras dan getas

- Kekuatan tarik rendah

- Kekuatan Tekan Tinggi

- Isolator yang baik

- Tahan korosi

- Tahan pada temperatur tinggi 


\section{POLIMER}

Klasifikasi polimer dapat dibagi berdasarkan :

*) Sumber atau asal

- alam : hewan, tumbuhan, dan mineral

- Sintetis : hasil polimerisasi hasil polimer adisi

*) Sifat termal

- Termoplastik (selulosa, polisterin, Vinil)

- Termoseting plastik (phenol, amino, furan, gemuk)

Sifat-sifat umum dari polimer

- Ringan (masa jenis relatif rendah)

- Tidak tahan temperatur tinggi

- Kekuatan tarik rendah dan keuletan tinggi

- Isolator yang baik

- Modulus elastisitas rendah

\section{KOMPOSIT}

Komposit merupakan gabungan dua jenis bahan atau lebih yang terdiri dari SERAT dan MATRIK, keduanya digabung dengan konstruksi tertentu tanpa mengubah sifat-sifat bahan penyusunnya.

Contoh beberapa jenis serat :

- $\quad$ serat gelas

- serat karbon

- serat polimer

- serat logam

\section{SIFAT - SIFAT MATERIAL DAN PENGUJIAN}

Pemilihan bahan dalam perancangan suatu komponen atau produk adalah berdasarkan sifat - sifat yang dimiliki oleh bahan tersebut dan disesuaikan dengan 
fungsi serta prinsip kerja dari komponen yang dirancang. Jadi yang dimanfaatkan dari suatu material adalah sifatnya.

\section{Sifat-Sifat Material}

Material memiliki sifat diantaranya sifat mekanik yaitu sifat yang menyatakan kemampuan suatu material / komponen untuk menerima beban, gaya dan energi tanpa menimbulkan kerusakan pada material/komponen tersebut.

Pembagian Sifat - Sifat Secara Umum.

\section{A. SIFAT MEKANIK}

Sifat mekanik adalah sifat yang menunjukkan kelakuan material apabila material tersebut diberi beban mekanik (statik atau dinamik), contoh sifat mekanik diantaranya adalah :

1. Kekuatan (strength)

Merupakan kemampuan suatu material untuk menerima tegangan tanpa menyebabkan material menjadi patah. Berdasarkan pada jenis beban yang bekerja, kekuatan dibagi dalam beberapa macam yaitu kekuatan tarik, kekuatan geser, kekuatan tekan, kekuatan torsi, dan kekuatan lengkung.

2. Kekakuan (stiffness)

Adalah kemampuan suatu material untuk menerima tegangan/beban tanpa mengakibatkan terjadinya deformasi atau difleksi.

3. Kekenyalan (elasticity)

Didefinisikan sebagai kemampuan meterial untuk menerima tegangan tanpa mengakibatkan terjadinya perubahan bentuk yang permanen setelah tegangan dihilangkan, atau dengan kata lain kemampuan material untuk kembali ke bentuk dan ukuran semula setelah mengalami deformasi (perubahan bentuk).

4. Plastisitas (plasticity)

Adalah kemampuan material untuk mengalami deformasi plastik (perubahan bentuk secara permanen) tanpa mengalami kerusakan. 
Material yang mempunyai plastisitas tinggi dikatakan sebagai material yang ulet (ductile), sedangkan material yang mempunyai plastisitas rendah dikatakan sebagai material yang getas (brittle).

5. Keuletan (ductility)

Adalah suatu sifat material yang digambarkan seperti kabel dengan aplikasi kekuatan tarik. Material ductile ini harus kuat dan lentur. Keuletan biasanya diukur dengan suatu periode tertentu, persentase keregangan. Sifat ini biasanya digunakan dalam bidan perteknikan, dan bahan yang memiliki sifat ini antara lain besi lunak, tembaga, aluminium, nikel, dll.

6. Ketangguhan (toughness)

Merupakan kemampuan material untuk menyerap sejumlah energi tanpa mengakibatkan terjadinya kerusakan.

7. Kegetasan (brittleness)

Adalah suatu sifat bahan yang mempunyai sifat berlawanan dengan keuletan. Kerapuhan ini merupakan suatu sifat pecah dari suatu material dengan sedikit pergeseran permanent. Material yang rapuh ini juga menjadi sasaran pada beban regang, tanpa memberi regangan yang terlalu besar. Contoh bahan yang memiliki sifat kerapuhan ini yaitu besi cor.

8. Kelelahan (fatigue)

Merupakan kecenderungan dari logam untuk menjadi patah bila menerima beban bolak-balik (dynamic load) yang besarnya masih jauh di bawah batas kekakuan elastiknya.

9. Melar (creep)

Merupakan kecenderungan suatu logam untuk mengalami deformasi plastik bila pembebanan yang besarnya relatif tetap dilakukan dalam waktu yang lama pada suhu yang tinggi. 


\section{Kekerasan (hardness)}

Merupakan ketahanan material terhadap penekanan atau indentasi / penetrasi. Sifat ini berkaitan dengan sifat tahan aus (wear resistance) yaitu ketahanan material terhadap penggoresan atau pengikisan.

\section{B. SIFAT FISIK - SIFAT KIMIA}

Sifat fisik dan kimia adalah suatu sifat yang berkaitan dengan karakteristik fisik atau kondisi dari material, contoh sifat fisik sifat kimia dari suatu material diantaranya adalah :
a.) Titik Cair
b.) Konduktivitas panas dan listrik
c.) Massa Jenis
d.) Warna
e.) Ketahanan Korosi

\section{SIFAT TEKNOLOGI}

Sifat teknologi adalah suatu sifat yang berkaitan dengan kemudahan material tersebut untuk diproses lebih lanjut, contoh dari sifat teknologi diantaranya adalah :

a.) Mampu Mesin: Kemampuan suatu material untuk di potong, dengan menggunakan alat - alat potong (pahat, gergaji, kikir, dan gerinda). Proses pemotongan akan terjadi apabila ada gerak relative antara benda kerja dan pahat potong.

b.)Mampu Cor: Kemampuan suatu material untuk dicairkan dan dituang ke dalam cetakan tanpa adanya cacat (cacat seperti : patah, retak, porositas, dan segregasi).

c.) Mampu Las: Kemampuan suatu material untuk disambung dengan menggunakan panas tanpa adanya cacat seperti (fasa keras, retak, dan distorsi) 
d.)Mampu Bentuk: Kemampuan suatu material untuk dideformasi plastis dengan tidak terjadinya necking dan beban yang diperlukan rendah. (necking adalah pengecilan penampang pada saat deformasi plastis berlangsung)

\section{Pengujian Material}

Dalam pemanfaatan material harus mempertimbangkan ketiga sifat diatas untuk mendapatkan hasil yang optimum dalam suatu perancangan. Untuk mengetahui sifat - sifat material di atas harus dilakukan pengujian atau evaluasi dengan tujuan untuk mendapatkan material yang sesuai dengan klasifikasinya.

Pengujian pada material secara umum dapat dibagi menjadi dua bagian yaitu :

1.) Pengujian Merusak (Destructive Test)

Pengujian ini bersifat merusak benda kerja, sehingga dalam pengujian ini dibutuhkan specimen uji. (specimen uji adalah duplikat dari benda kerja yang berasal dari bahan yang sama)

\section{2.) Pengujian Tidak Merusak (Non Destructive Test)}

Pengujian ini tidak merusak benda kerja, jadi tidak dibutuhkan spesimen uji dan dapat langsung di uji pada benda kerja. Hal ini dilakukan dengan tujuan untuk melihat cacat permukaan maupun dibawah permukaan benda kerja.

\section{PENGUJIAN MERUSAK}

Pengujian merusak dilakukan untuk mengetahui sifat-sifat mekanik dari material, dimana pengujiannya dengan pemberian beban mekanik hingga spesimen mengalami perubahan bentuk atau deformasi plastis ( merusak bentuk spesimen dari bentuk awal ).

Beberapa jenis pengujian mekanik:
1. Uji Tarik
2. Uji Impak
5. Uji Lelah
2. Uji Keras
4. Uji Mulur 
Beberapa Contoh Pengujian Merusak

\section{Uji Tarik}

Tujuan dari dilakukannya suatu pengujian mekanis adalah untuk menentukan respon material dari suatu konstruksi, komponen atau rakitan fabrikasi pada saat dikenakan beban atau deformasi dari luar. Dalam hal ini akan ditentukan seberapa jauh perilaku inheren (sifat yang lebih merupakan ketergantungan atas fenomena atomik maupun mikroskopis dan bukan dipengaruhi bentuk atau ukuran benda uji) dari material terhadap pembebanan tersebut.

Di antara semua pengujian mekanis tersebut, pengujian tarik merupakan jenis pengujian yang paling banyak dilakukan karena mampu memberikan informasi representatif dari perilaku mekanis material.

\section{Prinsip Pengujian :}

Sampel atau benda uji dengan ukuran dan bentuk tertentu ditarik dengan beban kontinyu sambil diukur pertambahan panjangnya. Data yang didapat berupa perubahan panjang dan perubahan beban yang selanjutnya ditampilkan dalam bentuk grafik teganganregangan. Data-data penting yang diharapkan didapat dari pengujian tarik ini adalah perilaku mekanik material dan karakteristik perpatahan.

Pengujian tarik yang dilakukan pada suatu material padatan (logam dan nonlogam) dapat memberikan keterangan yang relatif lengkap mengenai perilaku material tersebut terhadap pembebanan mekanis. Informasi penting yang bisa didapat adalah:

\section{a. Batas proporsionalitas (proportionality limit)}

Merupakan daerah batas dimana tegangan dan regangan mempunyai hubungan proporsionalitas satu dengan lainnya. Setiap penambahan tegangan akan diikuti dengan penambahan regangan secara proporsional dalam hubungan linier $\sigma=$ 
$\boldsymbol{E} \boldsymbol{\varepsilon}$ (bandingkan dengan hubungan $\boldsymbol{y}=\boldsymbol{m} \boldsymbol{x}$; dimana $\boldsymbol{y}$ mewakili tegangan; $\boldsymbol{x}$ mewakili regangan dan $\boldsymbol{m}$ mewakili slope kemiringan dari modulus kekakuan). Titik $\mathrm{P}$ pada gambar di bawah ini menunjukkan batas proporsionalitas dari kurva teganganregangan.

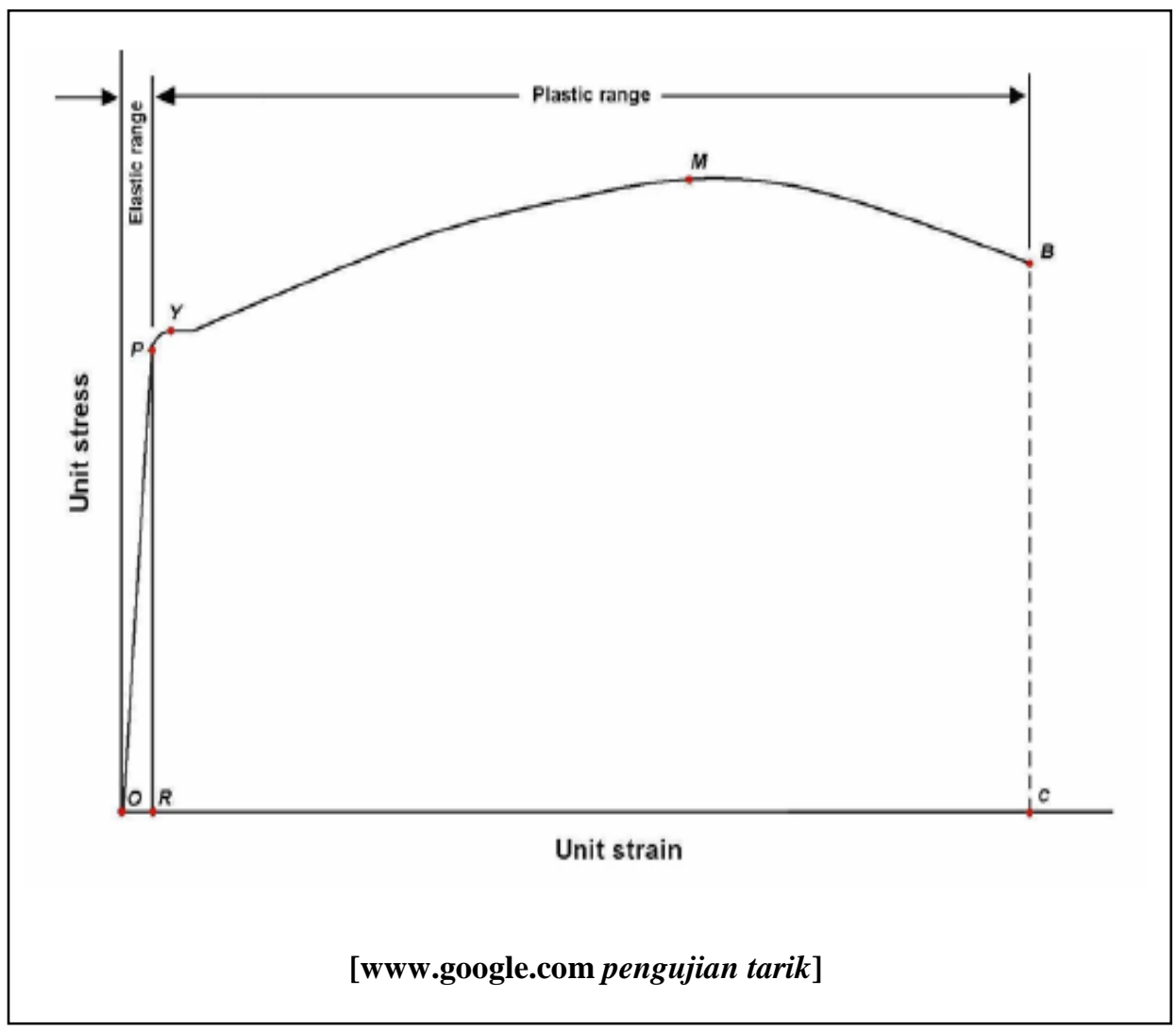

\section{b. Batas elastis (elastic limit)}

Daerah elastis adalah daerah dimana bahan akan kembali kepada panjang semula bila tegangan luar dihilangkan. Daerah proporsionalitas merupakan bahagian dari batas elastik ini. Selanjutnya bila bahan terus diberikan tegangan (deformasi dari luar) maka batas elastis akan terlampaui pada akhirnya sehingga bahan tidak akan kembali kepada ukuran semula. Dengan kata lain dapat didefinisikan bahwa batas elastis merupakan suatu titik dimana tegangan yang diberikan akan menyebabkan terjadinya deformasi permanen (plastis) pertama kalinya. Kebanyakan material teknik memiliki batas elastis yang hampir berimpitan dengan batas 
proporsionalitasnya.

\section{c. Titik luluh (yield point) dan kekuatan luluh (yield strength)}

Titik ini merupakan suatu batas dimana material akan terus mengalami deformasi tanpa adanya penambahan beban. Tegangan (stress) yang mengakibatkan bahan menunjukkan mekanisme luluh ini disebut tegangan luluh (yield stress). Titik luluh ditunjukkan oleh titik Y pada Gambar di atas. Gejala luluh umumnya hanya ditunjukkan oleh logam-logam ulet dengan struktur Kristal BCC dan FCC yang membentuk interstitial solid solution dari atom-atom carbon, boron, hidrogen dan oksigen. Interaksi antara dislokasi dan atom-atom tersebut menyebabkan baja ulet eperti mild steel menunjukkan titik luluh bawah (lower yield point) dan titik luluh atas (upper yield point).

Baja berkekuatan tinggi dan besi tuang yang getas umumnya tidak memperlihatkan batas luluh yang jelas. Untuk menentukan kekuatan luluh material seperti ini maka digunakan suatu metode yang dikenal sebagai Metode Offset. Dengan metode ini kekuatan luluh (yield strength) ditentukan sebagai tegangan dimana bahan memperlihatkan batas penyimpangan/deviasi tertentu dari proporsionalitas tegangan dan regangan .

Pada Gambar di bawah ini garis offset OX ditarik paralel dengan OP, sehingga perpotongan XW dan kurva tegangan-regangan memberikan titik Y sebagai kekuatan luluh. Umumnya garis offset OX diambil $0.1-0.2 \%$ dari regangan total dimulai dari titik $\mathrm{O}$. 


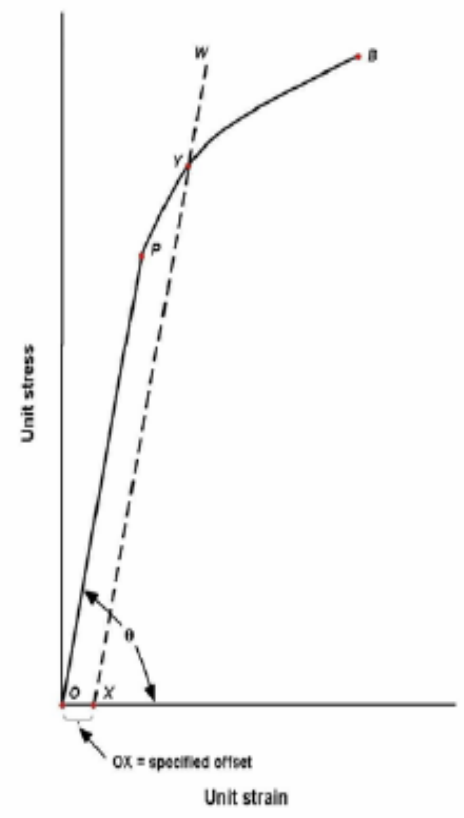

[www.google.com pengujian tarik]

\section{Mode Perpatahan Material}

Sampel hasil pengujian tarik dapat menunjukkan beberapa tampilan perpatahan seperti diilustrasikan oleh Gambar di bawah ini :
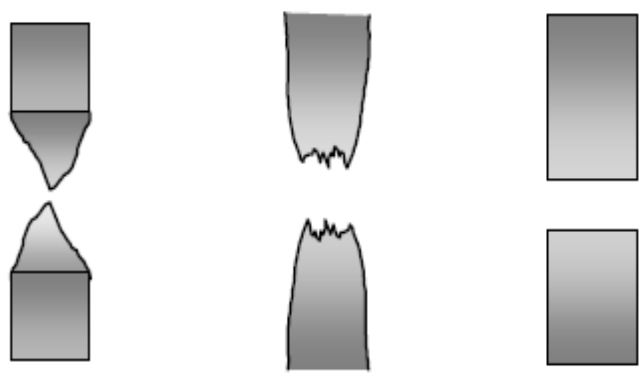

Sangat ulet

[www.google.com pengujian tarik] 


\section{Uji Keras}

Pengujian Kekerasan adalah satu dari sekian banyak pengujian yang dipakai, karena dapat dilaksanakan pada benda uji yang kecil tanpa kesukaran mengenai spesifikasi. Kekerasan (Hardness) adalah salah satu sifat mekanik (Mechanical properties) dari suatu material. Kekerasan suatu material harus diketahui khususnya untuk material yang dalam penggunaanya akan mangalami pergesekan (frictional force) dan dinilai dari ukuran sifat mekanis material yang diperoleh dari deformasi plastis (deformasi yang diberikan dan setelah dilepaskan, tidak kembali ke bentuk semula akibat indentasi oleh suatu menda sebagai alat uji.

Dalam hal ini bidang keilmuan yang berperan penting mempelajarinya adalah Ilmu Bahan Teknik (Metallurgy Engineering). Mengapa diperlukan pengujian kekerasan? Di dalam aplikasi manufaktur, material terutama semata diuji untuk dua pertimbangan: yang manapun ke riset karakteristik suatu material baru dan juga sebagai suatu cek mutu untuk memastikan bahwa contoh material tersebut menemukan spesifikasi kualitas tertentu .

Pengujian yang paling banyak dipakai adalah dengan menekankan penekan tertentu kepada benda uji dengan beban tertentu dan dengan mengukur ukuran bekas penekanan yang terbentuk diatasnya, cara ini dinamakan cara kekerasan dengan penekanan. Kekerasan juga didefinisikan sebagai kemampuan suatu material untuk menahan beban identasi atau penetrasi (penekanan). Didunia teknik, umumnya pengujian kekerasan menggunakan 4 macam metode pengujian kekerasan, yakni :

1. Brinnel (HB / BHN)

2. Rockwell (HR / RHN)

3. Vikers (HV / VHN)

4. Micro Hardness (Namun jarang sekali dipakai) 


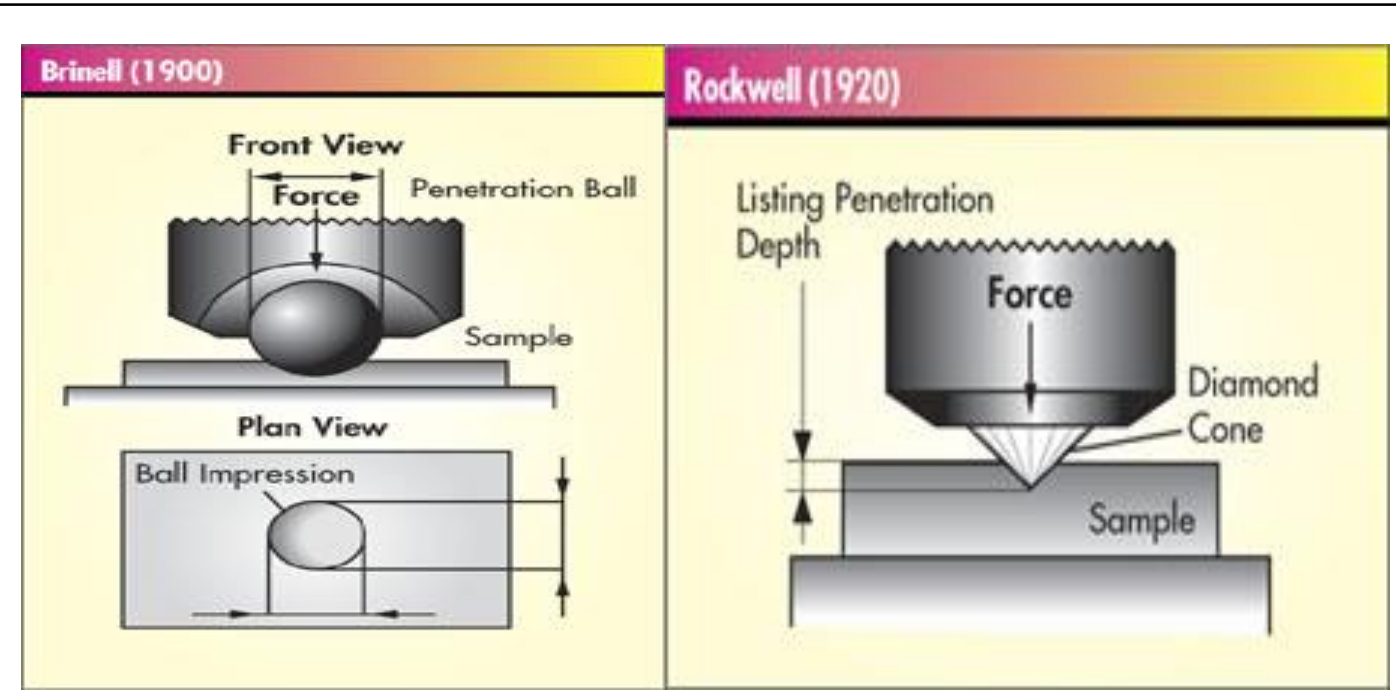

Vickers (1924)

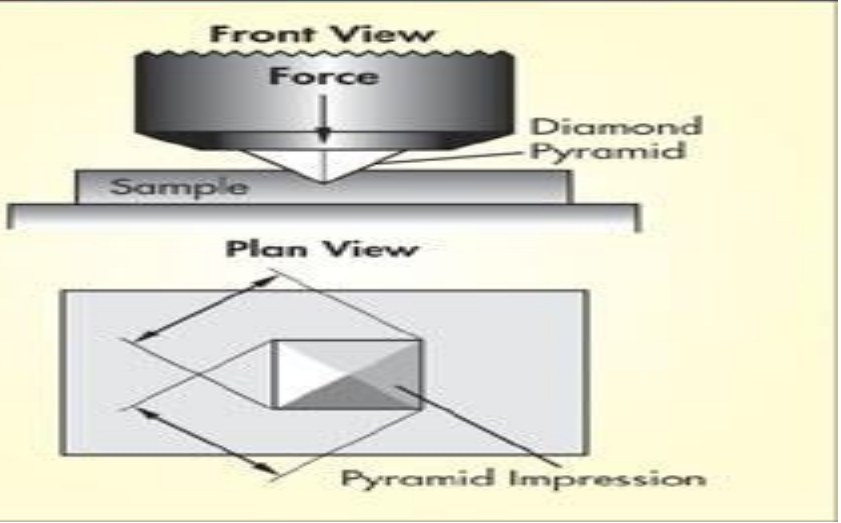

[www.google.com pengujian kekerasan]

Pengujian Rockwell cocok untuk semua material yang keras dan yang lunak, penggunaannya sederhana dan penekanannya dapat dilakukan dengan leluasa. Tabel di bawah menunjukkan bagaimana memilih skala Rockwell 


\begin{tabular}{|c|c|c|c|c|c|c|}
\hline \multirow{2}{*}{ Skala } & \multirow{2}{*}{ Penekan } & \multicolumn{3}{|c|}{ Beban } & \multirow{2}{*}{$\begin{array}{c}\text { Skala } \\
\text { Kekerasan }\end{array}$} & \multirow{2}{*}{ Warna Angka } \\
\hline & & Awal & Utama & Jumlah & & \\
\hline A & Kenucut Irtan $120^{\circ}$ & 10 & 50 & 60 & 100 & \multirow[b]{2}{*}{ Hitam } \\
\hline B & Bola Baja 1,588 mm $\left(1 / 6^{\prime \prime}\right)$ & 10 & 90 & 100 & 130 & \\
\hline C & Kenucut Intan $120^{\circ}$ & 10 & 140 & 150 & 100 & \multirow{2}{*}{$\begin{array}{l}\text { Merah } \\
\text { Hitam }\end{array}$} \\
\hline D & Kenucut Intan $120^{\circ}$ & 10 & 90 & 100 & 100 & \\
\hline E & Bola Baja 3,175 mm(1/8") & 10 & 90 & 100 & 130 & \multirow{2}{*}{ Merah } \\
\hline F & Bola Baja 1,588 mm $\left(1 / 6^{\prime \prime}\right)$ & 10 & 50 & 60 & 130 & \\
\hline G & Bola Baja 1,588 $\mathrm{mm}\left(1 / 6^{\prime \prime}\right)$ & 10 & 140 & 150 & 130 & Merah \\
\hline $\mathrm{H}$ & Bola Baja 3,175 mm $\left(1 / 8^{\prime \prime}\right)$ & 10 & 50 & 60 & 130 & \multirow{2}{*}{ Merah } \\
\hline $\mathrm{K}$ & Bola Baja $3,175 \mathrm{~mm}\left(1 / 8^{\prime \prime}\right)$ & 10 & 140 & 150 & 130 & \\
\hline L & Bola Baja 6,35 mm(1/4") & 10 & 50 & 60 & 130 & \multirow{2}{*}{$\begin{array}{c}\text { Merah } \\
\text { MerahMerah }\end{array}$} \\
\hline M & Bola Baja 6,35 mm(1/4") & 10 & 90 & 100 & 130 & \\
\hline$P$ & Bola Baja 6,35 mm(1/4') & 10 & 140 & 150 & 130 & Merah \\
\hline $\mathrm{R}$ & Bola Baja 12,7 mm(1/2') & 10 & 50 & 60 & 130 & \multirow{2}{*}{ Merah } \\
\hline S & Bola Baja $12,7 \mathrm{~mm}\left(1 / 2^{\prime}\right)$ & 10 & 90 & 100 & 130 & \\
\hline V & Bola Baja 12,7 mm(1/2) & 10 & 140 & 150 & 130 & Merah \\
\hline
\end{tabular}

[www.google.com pengujian kekerasan]

Dalam pengujian kekerasan seperti pada pengujian statik lainnya, diukur ketahanan terhadap deformasi, tetapi ukuran penekan beban dan ukuran penekanan derajat pengerasan regangan, berbeda. Jadi pertama korelasi antara kekerasan yang diperoleh dengan berbagai cara pengujian kekerasan menjadi permasalahan

Tidak ada cara lain kecuali mendapatkan hubungan tersebut secara eksperimen, jadi kekerasan yang diperoleh dengan berbagai cara ditulis sebagai tabel konversi kekerasan. Tetapi hal yang diutarakan di atas berbeda menurut bahan, oleh karena itu untuk baja atau paduan tembaga perlu memakai tabel yang berlainan sesuai dengan paduan mesing-masing.

Sejumlah data tersedia berkenaan dengan hubungan antara kekerasan dan kekuatan tarik atau kekuatan lelah. Hubungan ini sangan memudahkan untuk mengetahui kekuatan bahan dengan pengujian sederhana dari kekerasan. Tetapi karena hubungan itu memuat banyak faktor variabel, perlu berhati-hati dalam penggunaannya. Sebagai tambahan dalam penggunaan bagi bahan yang sama jenisnya, disarankan untuk memperhatikan metalografinya. 


\section{Uji Impak}

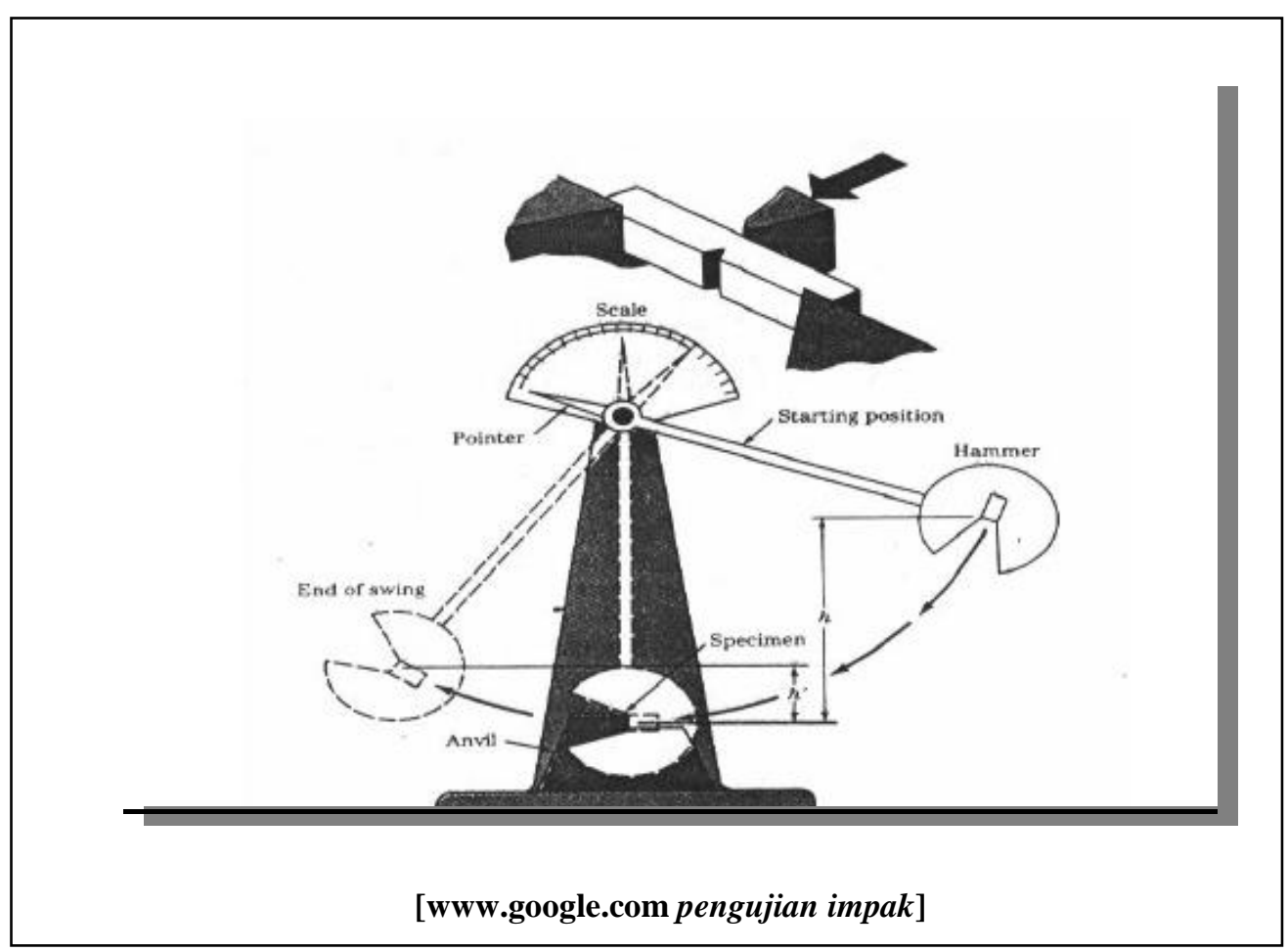

Dasar pengujian impak ini adalah penyerapan energi potensial dari pendulum beban yang berayun dari suatu ketinggian tertentu dan menumbuk benda uji sehingga benda uji mengalami deformasi.

Pada pengujian impak ini banyaknya energi yang diserap oleh bahan untuk terjadinya perpatahan merupakan ukuran ketahanan impak atau ketangguhan bahan tersebut. Pada Gambar di atas dapat dilihat bahwa setelah benda uji patah akibat deformasi, bandul pendulum melanjutkan ayunannya hingga posisi $h$ '.

Bila bahan tersebut tangguh yaitu makin mampu menyerap energi lebih besar maka makin rendah posisi $h$ '. Suatu material dikatakan tangguh bila memiliki kemampuan menyerap beban kejut yang besar tanpa terjadinya retak atau terdeformasi dengan mudah. Pada pengujian impak, energi yang diserap oleh benda uji biasanya dinyatakan dalam satuan Joule dan dibaca langsung pada skala (dial) penunjuk yang telah dikalibrasi yang terdapat pada mesin penguji. Harga impak (HI) suatu bahan yang diuji dengan metode Charpy 
diberikan oleh :

$$
H I=E / A
$$

Dimana $\mathbf{E}$ adalah energi yang diserap dalam satuan Joule dan A luas penampang di bawah takik dalam satuan $\mathrm{mm}^{2}$. Secara umum benda uji impak dikelompokkan ke dalam dua golongan sampel standar yaitu :

Batang uji Charpy banyak digunakan di Amerika Serikat dan batang uji Izod yang lazim digunakan di Inggris dan Eropa. Benda uji Charpy memiliki luas penampang lintang bujur sangkar $(10 \times 10 \mathrm{~mm})$ dan memiliki takik (notch) berbentuk V dengan sudut 45 , dengan jari-jari dasar $0,25 \mathrm{~mm}$ dan kedalaman $2 \mathrm{~mm}$.

Benda uji diletakkan pada tumpuan dalam posisi mendatar dan bagian yang bertakik diberi

beban impak dari ayunan bandul. Benda uji Izod mempunyai penampang lintang bujur sangkar atau lingkaran dengan takik V di dekat ujung yang dijepit. Perbedaan cara pembebanan antara metode Charpy dan Izod ditunjukkan oleh gambar dibawah ini.

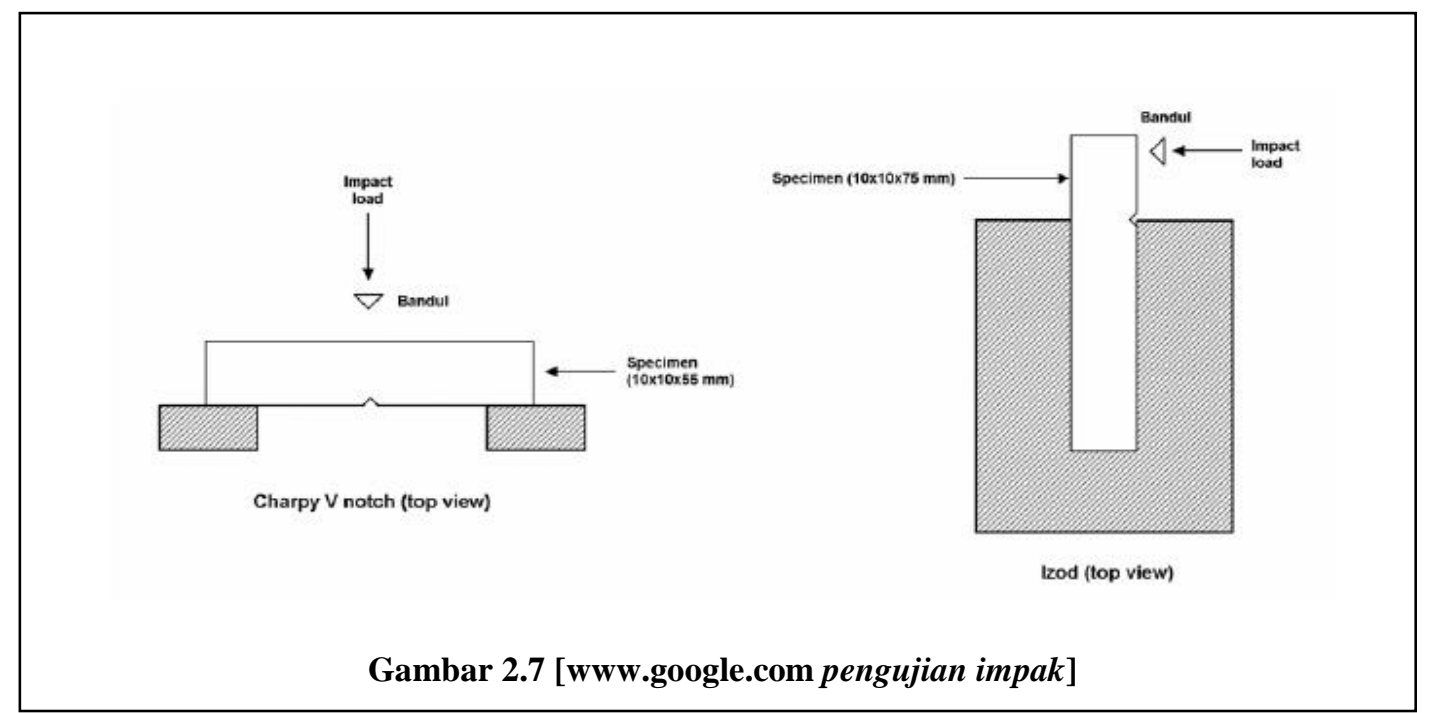

Serangkaian uji Charpy pada satu material umumnya dilakukan pada berbagai temperature sebagai upaya untuk mengetahui temperatur transisi (akan diterangkan pada paragraph - paragraf selanjutnya). Sementara uji impak dengan metode Izod umumnya 
dilakukan hanya pada temperatur ruang dan ditujukan untuk material-material yang didisain untuk berfungsi sebagai cantilever.

Takik (notch) dalam benda uji standar ditujukan sebagai suatu konsentrasi tegangan sehingga

perpatahan diharapkan akan terjadi di bagian tersebut. Selain berbentuk V dengan sudut $45^{\circ}$, takik dapat pula dibuat dengan bentuk lubang kunci (key hole).

Pengukuran lain yang biasa dilakukan dalam pengujian impak Charpy adalah penelaahan permukaan perpatahan untuk menentukan jenis perpatahan (fracografi) yang terjadi. Secara umum sebagaimana analisis perpatahan pada benda hasil uji tarik maka perpatahan impak digolongkan menjadi 3 jenis, yaitu:

1. Perpatahan berserat (fibrous fracture), yang melibatkan mekanisme pergeseran bidang - bidang kristal di dalam bahan (logam) yang ulet (ductile). Ditandai dengan permukaan patahan berserat yang berbentuk dimpel yang menyerap cahaya dan berpenampilan buram.

2. Perpatahan granular/kristalin, yang dihasilkan oleh mekanisme pembelahan (cleavage) pada butir-butir dari bahan (logam) yang rapuh (brittle). Ditandai dengan permukaan patahan yang datar yang mampu memberikan daya pantul cahaya yang tinggi (mengkilat).

3. Perpatahan campuran (berserat dan granular). Merupakan kombinasi dua jenis perpatahan di atas. 


\section{DAFTAR PUSTAKA}

1. Sato, G. Takeshi dan Sugiarto, N.1999. Menggambar Mesin . Jakarta : Pradnya Paramita.

2. Staf Pengajar Tata Tulis Karya Ilmiah 2004. Tata Tulis Karya Ilmiah. 2004. Bandung : Departemen Sosioteknologi Institut Teknologi Bandung.

3. www.google.com / pembentukan material.

4. www.google.com/ proses pengelasan.

5. Irwan, Yusril,2010. Proses Pengelasan. Bandung.

6. Hidayat, W. (2019, April 2). ANALISIS TEGANGAN GESER, MOMEN DAN TEGANGAN LENTUR MAKSIMUM UNTUK PEMBUATAN PISAU PADA RANCANG BANGUN MESIN PEMECAH BUAH KAKAO KAPASITAS 2 TON/JAM. https://doi.org/10.31227/osf.io/nu64a 